\title{
Syndactyly type 4
}

INSERM

\section{Source}

INSERM. (1999). Orphanet: an online rare disease and orphan drug data base. Syndactyly type 4. ORPHA:93405

Syndactyly type 4 (SD4) is a very rare congenital distal limb malformation characterized by complete bilateral syndactyly (involving all digits 1 to 5 ). 